\title{
KSZTAŁTOWANIE TRENDÓW W ROZWOJU ,ZIELONYCH” ZAMÓWIEŃ PUBLICZNYCH W ŚWIETLE UREGULOWAŃ WSPÓLNOTOWYCH
}

\section{PODSTAWY PRAWNE GPP}

Termin ,zielone zamówienie” odnosi się do takich typów postępowań, $\mathrm{w}$ których to zamówienie uwzględnia przynajmniej jeden $\mathrm{z}$ czynników środowiskowych już na etapie określenia potrzeb, zdefiniowania przedmiotu zamówienia, sformułowania specyfikacji technicznych, wyboru kryteriów udzielenia zamówienia lub sposobu wykonania zamówienia. Celem zielonych zamówień publicznych (ang. Green Public Procurement - GPP) jest uwzględnianie kwestii środowiskowych w procedurach przetargowych w możliwie najszerszym zakresie. Główną ideą ekologicznych zamówień publicznych jest ustalenie jasnych i ambitnych kryteriów środowiskowych dla produktów i usług.

Podstawowym aktem regulującym kwestie dotyczące udzielania zamówień publicznych w Polsce jest oczywiście ustawa - Prawo zamówień publicznych z 29 stycznia 2004 r. ${ }^{1}$, która bezpośrednio do kwestii środowiskowych odnosi się w art. 30 ust. 6 oraz art. 91 ust. 2 . W treści art. 30 ustawodawca wskazał wprost, że wymagania funkcjonalne odnoszące się do opisu przedmiotu zamówienia mogą obejmować opis oddziaływania na środowisko. Ustęp 6 art. 30 przewiduje możliwość zastąpienia opisu przedmiotu zamówienia z zachowaniem norm, aprobat, specyfikacji technicznych i systemów odniesienia poprzez wskazanie wymagań funkcjonalnych ${ }^{2}$. Wymagania te moga obejmować np. opis oddziaływania na środowisko. Jak trafnie zauważa M. Pużański, w pkt 29 preambuły do dyrektywy 2004/18/WE koordynującej procedury udzielania zamówień publicznych na roboty budowlane, dostawy i usługi ,instytucje zamawiajace, które chcą zdefiniować wymagania dotyczące ochrony środowiska, w ramach specyfikacji technicznej danego zamówienia, moga określić aspekty środowiskowe, obejmujące, na przykład, metody produkcji lub specyficzny wpływ grupy produktów lub usług na środowisko" ${ }^{3}$. Na uwagę zasługuje wyraz „,moga”" jednoznacznie przemawiający za fakultatywnością takiego rozwiązania. Artykuł 91 ust. 2 odnoszący się do kryteriów oceny ofert wskazuje, że owymi

${ }^{1}$ Ustawa z 29 stycznia 2004 r. - Prawo zamówień publicznych, Dz. U. Nr 19, poz. 177 (dalej jako: PzP).

${ }^{2}$ M. Płużański, Prawo zamówień publicznych. Komentarz, 2009, komentarz do art. 60 PzP, Legalis, P. Granecki, Prawo zamówień publicznych. Komentarz, Warszawa 2012, komentarz do art. 60 PzP, Legalis.

${ }^{3}$ Ibidem. 
kryteriami sa cena albo cena i inne kryteria odnoszące się do przedmiotu zamówienia, w szczególności jakość, funkcjonalność, parametry techniczne, jak również zastosowanie najlepszych dostępnych technologii w zakresie oddziaływania na środowisko, koszty eksploatacji, serwis oraz termin wykonania zamówienia ${ }^{4}$. W prawie Wspólnoty Europejskiej proces zamówień publicznych reguluja dyrektywy: nr 2004/17/WE Parlamentu Europejskiego i Rady z 31 marca 2004 r. koordynująca procedury udzielania zamówień przez podmioty działające w sektorach gospodarki wodnej, energetyki, transportu i usług pocztowych ${ }^{5}$ oraz nr 2004/18/WE Parlamentu Europejskiego i Rady z 31 marca 2004 r. w sprawie koordynacji procedur udzielania zamówień publicznych na roboty budowlane, dostawy i usługi ${ }^{6}$. Przepisy wskazanych dyrektyw odnosza się m.in. w sposób bezpośredni do zagadnień zielonych zamówień publicznych ${ }^{7}$. $\mathrm{Na}$ szczeblu UE politykę zielonych zamówień publicznych kształtują przede wszystkim komunikaty Komisji ${ }^{8}$.

Tak zwane zielone zamówienia (czyli tzw. Green Public Procurement) to polityka, w ramach której podmioty publiczne włączają kryteria i wymagania ekologiczne do procesu zakupów, a zatem do procedur udzielania zamówień publicznych $^{9}$. Zgodnie $\mathrm{z}$ tą polityką podmioty publiczne poszukują rozwiązań ograniczających negatywny wpływ produktów bądź usług na środowisko ${ }^{10}$.

${ }^{4}$ Szerzej zob. M. Pchałek, A. Jachnik, P. Kupczyk, Prawne aspekty ,zielonych” zamówień publicznych, w: Zielone zamówienia publiczne, Urząd Zamówień Publicznych, Warszawa 2009, s. 9-47.

${ }^{5}$ Dz. Urz. UE L 134 z 30 kwietnia 2004 r. (dalej jako: dyrektywa 2004/17/WE lub tzw. dyrektywa sektorowa).

${ }^{6}$ Dz. Urz. UE L 134 z 30 kwietnia 2004 r. (dalej jako: dyrektywa 2004/18/WE, tzw. dyrektywa klasyczna).

${ }^{7}$ Zob. http://www.zielonezamowienia.gov.pl.

${ }^{8}$ Należy wśród nich wymienić przede wszystkim: Komunikat Komisji w sprawie prawa wspólnotowego mającego zastosowanie do zamówień publicznych oraz możliwości włączenia aspektów środowiskowych do zamówień publicznych, KOM (2001), 274, którego celem była analiza oraz wskazanie możliwości włączania aspektów środowiskowych w procedury zamówień publicznych w ramach obowiązujących wspólnotowych ram prawnych w taki sposób, aby podmioty zamawiające mogły poprzez zamówienia publiczne przyczyniać się do realizacji wyzwań zrównoważonego rozwoju. Ponadto Komunikat Komisji - Zamówienia publiczne na rzecz poprawy stanu środowiska, KOM (2008), 400, który stanowi kontynuację działań zmierzających do „zazielenienia” zamówień publicznych w ramach Unii Europejskiej i zaleca przejęcie przez państwa członkowskie kryteriów GPP opracowanych dla grup wyrobów i usług w 10 sektorach priorytetowych. Mając na uwadze znaczny potencjał zielonych zamówień wspierających rozwój innowacyjnej gospodarki, w kształtowaniu polityki produktowej i rozwoju technologii środowiskowych, warto także wskazać Komunikat Komisji dotyczący zintegrowanej polityki produktowej (IPP), KOM (2003), 302, jak również Komunikat Komisji - Stymulowanie technologii dla zrównoważonego rozwoju, Plan Działań w dziedzinie Technologii Środowiskowych dla Unii Europejskiej (ETAP), KOM (2004), 38, czy Komunikat Komisji - Sprawozdanie z realizacji Planu Działania w dziedzinie Technologii Srodowiskowych w 2004 roku - KOM (2005), 16 i Odnowiona Strategia Zrównoważonego Rozwoju UE, 10917/06. Można również wymienić takie dokumenty, jak Komunikat Komisji dotyczący planu działania na rzecz zrównoważonej konsumpcji i produkcji oraz zrównoważonej polityki przemysłowej, KOM (2008), 397; Komunikat Komisji Inicjatywa rynków pionierskich dla Europy, KOM (2007), 860; Komunikat Komisji - Sprawozdanie Komisji dla Rady, Parlamentu Europejskiego, Europejskiego Komitetu Ekonomiczno-Społecznego i Komitetu Regionów na temat stanu wdrażania Zintegrowanej Polityki Produktowej, KOM (2009), 693 i Komunikat Komisji - EUROPA 2020 Strategia na rzecz inteligentnego i zrównoważonego rozwoju sprzyjającego włączeniu społecznemu, KOM (2010), 2020 .

9200 A. Matusiak, Zamówienia publiczne na rzecz poprawy stanu środowiska, „Zamówienia Publiczne. Doradca" 2013, nr 2, s. 65.

10 Szerzej zob. http://ec.europa.eu/environment/gpp/index_en.htm. 
Takimi działaniami wpływają na rozwój i upowszechnienie technologii środowiskowych. Nie wolno zapominać, że na instytucjach publicznych przy udzielaniu zamówień ciąży obowiązek rzetelnego postępowania, co oznacza, iż oprócz uzyskania najlepszej relacji jakości do ceny, konieczne jest stosowanie zasad przejrzystości, równego traktowania, niedyskryminacji i uczciwej konkurencji. Dokładnie te same zasady odnoszą się do postępowania przy zielonych zamówieniach.

\section{GPP W PRAKTYCE}

Problem jest naprawdę znaczący. Wystarczy odnieść się do skali zagadnienia. Odnotować bowiem należy, że europejskie instytucje publiczne wydaja równowartość $16 \%$ produktu krajowego brutto UE na zakup towarów, np. sprzętu biurowego, elementów budowlanych i pojazdów transportowych, usług (m.in. w zakresie utrzymania budynków, transportu, sprzątania i cateringu), oraz robót budowlanych każdego roku ${ }^{11}$. Jak potwierdziły badania, istnieją znaczące możliwości w zakresie efektywnych pod względem kosztów ekologicznych zamówień publicznych, w szczególności w sektorach, w których produkty ekologiczne nie są droższe od alternatywnych produktów nieekologicznych ${ }^{12}$. Jednym $\mathrm{z}$ celów Unii Europejskiej jest zrównoważony rozwój wszystkich państw członkowskich, ale nie tylko ${ }^{13}$.

Wyrazem proekologicznego podejścia jest stanowienie kolejnych aktów prawnych mających na celu urzeczywistnienie celów traktatowych. Przykładem niech będzie chociażby pkt 10 preambuły dyrektywy $2009 / 33 / \mathrm{WE}^{14}$ i zawarty w nim postulat: „Grupa wysokiego szczebla ds. konkurencyjności, energii i środowiska w swoim sprawozdaniu z 27.2.2007 r. stwierdziła, że w ramach zamówień publicznych i prywatnych należy brać pod uwagę koszty całego cyklu użytkowania, ze szczególnym uwzględnieniem efektywności energetycznej” ${ }^{15}$. Można także wskazać na komunikat nr 400 z 26 lipca 2008 r., w którym to Komisja Europejska ogłosiła, aby państwa członkowskie dążyły do udziału 50\% zielonych zamówień w procedurach przetargowych od $2010 \mathrm{r} .{ }^{16}$

\footnotetext{
${ }^{11}$ Komisja Wspólnot Europejskich, Bruksela, 16 lipca 2008 r., KOM (2008), 400 wersja ostateczna, Komunikat Komisji do Parlamentu Europejskiego, Rady, Europejskiego Komitetu Ekonomiczno-Społecznego oraz Komitetu Regionów: Zamówienia publiczne na rzecz poprawy stanu środowiska $\{$ SEK(2008) $2124\}\{\operatorname{SEK}(2008) 2125\}\{\operatorname{SEK}(2008) 2126\}$, s. 3.

${ }_{12}$ Komisja Wspólnot Europejskich, Bruksela, 16 lipca 2008 r., KOM (2008), 400 wersja ostateczna, Komunikat Komisji do Parlamentu Europejskiego, Rady, Europejskiego Komitetu Ekonomiczno-Społecznego oraz Komitetu Regionów: Zamówienia publiczne na rzecz poprawy stanu środowiska \{SEK(2008) $2124\}\{\operatorname{SEK}(2008) 2125\}\{\operatorname{SEK}(2008) 2126\}$ s. 3.

${ }^{13}$ Zrównoważoną politykę w zakresie zamówień zainicjowano w wielu krajach OECD (Stany Zjednoczone, Japonia, Kanada, Australia i Korea Południowa), a także w krajach szybko rozwijających się (takich jak Chiny, Tajlandia czy Filipiny). Zob. Krajowy plan działań w zakresie zrównoważonych zamówień publicznych na lata 2010-2012, Urząd Zamówień Publicznych, Warszawa, 2010, s. 5.

${ }^{14}$ Dyrektywa z 23 kwietnia 2009 r. w sprawie promowania ekologicznie czystych i energooszczędnych pojazdów transportu drogowego, Dz. Urz. UE L 2009, nr 120, poz. 5.

${ }^{15}$ A. Piotrowska, Innowacyjność a kryteria techniczne $w$ zamówieniach publicznych, w: Nowe podejście do zamówień publicznych - zamówienia publiczne jako instrument zwiększenia innowacyjności gospodarki $i$ zrównoważonego rozwoju. Doświadczenia polskie $i$ zagraniczne, cz. 1, Urząd Zamówień Publicznych, Warszawa 2009, nr 2, s. 27.

16 Ibidem, s. 27.
} 
Definicja i kryteria stosowane do identyfikowania i promowania „,bardziej ekologicznych" towarów opierają się na podejściu uwzględniającym cykl życia i obejmuja elementy, które wpływaja na cały łańcuch dostaw (od wyboru surowców, przez metody produkcji, aż po rodzaj stosowanych opakowań). Za pożądane należałoby uznać przyjęcie podejścia opartego na kalkulacji kosztów całego cyklu życia produktu. Mając bowiem na uwadze ten czynnik, należy przeanalizować i rozważyć nie tylko koszt zakupu towaru, lecz także koszty jego eksploatacji, a następnie utylizacji. Nie można bowiem zapominać, że znaczenie mają wszystkie koszty w całym cyklu życia danego produktów ${ }^{17}$. Powszechne uwzględnianie przez zamawiających koncepcji kosztu życia produktu (LCC -Life Cycle Costs ${ }^{18}$ ) może przyczynić się do wzrostu innowacyjności gospodarki całej UE ${ }^{19}$. Informacje dotyczące obliczania kosztu cyklu życia produktów czy usług przyjaznych dla środowiska sa niedostateczne ${ }^{20}$. Nie ma bowiem jednoznacznej opinii prawnej co do możliwości uwzględniania kryteriów środowiskowych $\mathrm{w}$ dokumentach przetargowych, brakuje skoordynowanej wymiany najlepszych praktyk i informacji między instytucjami regionalnymi i lokalnymi ${ }^{21}$. Za negatywny czynnik należy uznać fakt, że świadomość korzyści wynikających z przyjaznych dla środowiska produktów i usług nadal jest jeszcze bardzo niewielka. Pomimo zanotowanego wzrostu odsetka zielonych zamówień

17 Art. 2 pkt 1a ustawy - Prawo zamówień publicznych dodany ustawą z 12 października 2012 r., Dz. U. 2012, poz. 1271, która weszła w życie 20 lutego 2013 r., wprowadził do słownika Prawa zamówień publicznych termin ,,cykl życia produktu”. Zgodnie z nowo wprowadzoną definicją należy przez to rozumieć wszelkie możliwe kolejne fazy istnienia danego produktu, tj. badanie, rozwój, projektowanie przemysłowe, produkcję, naprawę, modernizację, zmianę, utrzymanie, logistykę, szkolenie, testowanie, wycofanie i usuwanie.

${ }^{18}$ Szerzej zob. J. Kulczycka, M. Góralczyk, Znaczenia $i$ możliwości stosowania oceny cyklu życia (LCA) i kosztów cyklu życia (LCC) w ekologicznych zamówieniach publicznych, w: Zielone zamówienia publiczne, s. 47-93.

19 Jak trafnie zauważa A. Piotrowska, każde zamówienie wiąże się z nieco odmiennym zbiorem potencjalnych czynników mających wpływ na środowisko. Zamówienia dotyczące dostaw, usług czy też robót budowlanych pociagają za sobą nieco inne konsekwencje. W wypadku zamówień na dostawy bierze się pod uwagę m.in. wpływ materiałów wykorzystanych do wytworzenia produktu na środowisko oraz wpływ procesów produkcji, ilość surowców odnawialnych w wytwarzaniu produkt, zużycie energii i wody przez produkt podczas jego użytkowania, trwałość produktu, możliwość recyklingu i chociażby takie kwestie, jak pakowanie i transport produktu. W wypadku zamówień na usługi liczy się wiedza techniczna i kwalifikacje pracowników w odniesieniu do wykonania zamówienia w sposób przyjazny dla środowiska, materiały wykorzystywane $\mathrm{w}$ świadczeniu usługi, procedury zarządzania wprowadzone w celu zminimalizowania wpływu usługi na środowisko, jak również zużycie energii i wody oraz odpady wytworzone w wyniku świadczenia usługi. Poza wszystkimi powyżej wymienionymi zagadnieniami w wypadku zamówień na roboty budowlane bierze się pod uwagę kwestię wpływu środowiska na użytkowanie gruntów czy też planowanie ruchu drogowego. Korzyści jest wiele, wciąż jednak liczne przeszkody, wśród których Komisja przede wszystkim wskazuje to, że nadal zdefiniowano niewiele kryteriów środowiskowych dla produktów bądź usług, a mechanizmy upowszechniania tych, które istnieją, takie jak bazy danych, są często niestety niewystarczające. Za: A. Piotrowska, op. cit., s. 27.

${ }^{20}$ Komisja Wspólnot Europejskich, Bruksela, 16 lipca 2008 r., KOM (2008), 400 wersja ostateczna, Komunikat Komisji do Parlamentu Europejskiego, Rady, Europejskiego Komitetu Ekonomiczno-Społecznego oraz Komitetu Regionów: Zamówienia publiczne na rzecz poprawy stanu środowiska \{SEK(2008) $2124\}\{\operatorname{SEK}(2008) 2125\}\{\operatorname{SEK}(2008) 2126\}$, s. 5.

${ }^{21}$ Komisja Wspólnot Europejskich, Bruksela, 16 lipca 2008 r., KOM (2008), 400 wersja ostateczna, Komunikat Komisji do Parlamentu Europejskiego, Rady, Europejskiego Komitetu Ekonomiczno-Społecznego oraz Komitetu Regionów: Zamówienia publiczne na rzecz poprawy stanu środowiska $\{\mathrm{SEK}(2008)$ $2124\}\{\operatorname{SEK}(2008) 2125\}\{\operatorname{SEK}(2008) 2126\}$, s. 5. 
publicznych na szczeblu krajowym ich udział w porównaniu z innymi, przodującymi w tej dziedzinie państwami członkowskimi nadal pozostaje niski. Zwiększenie stopnia uwzględniania aspektów środowiskowych w organizowanych postępowaniach o udzielenie zamówienia wynika ze wzrostu zainteresowania kwestiami środowiskowymi zamawiających oraz chęci prowadzenia przez nich polityki przetargowej zgodnej z zasadami zrównoważonego rozwoju ${ }^{22}$.

W UE po raz pierwszy potencjał ekologicznych zamówień publicznych podkreślono w komunikacie Komisji na temat zintegrowanej polityki produktowej z 2003 r. Zalecono w nim państwom członkowskim przyjęcie do końca 2006 r. krajowych planów działań w zakresie GPP. W nowych europejskich ramach prawnych ${ }^{23} \mathrm{w}$ zakresie zamówień wyjaśniono, w jaki sposób nabywcy publiczni mogą uwzględniać aspekty środowiskowe w swoich procesach i procedurach udzielania zamówień. W czerwcu 2006 r. w odnowionej strategii zrównoważonego rozwoju UE wyznaczono jako cel polityczny na $2010 \mathrm{r}$. doprowadzenie średniego poziomu unijnych ekologicznych zamówień publicznych do standardów osiągniętych przez przodujące państwa członkowskie w roku $2006^{24}$.

Komisja zidentyfikowała dziesięć priorytetowych sektorów dla ekologicznych zamówień publicznych. Uznała, że są nimi: budownictwo ${ }^{25}$; usługi gastronomiczne i cateringowe; transport i usługi transportowe, energetyka ${ }^{26}$; urządzenia biurowe i komputery ${ }^{27}$, odzież, uniformy i inne wyroby

${ }^{22}$ Krajowy plan działań w zakresie zrównoważonych zamówień publicznych na lata 2010-2012, Urząd Zamówień Publicznych, Warszawa 2010, s. 30.

${ }^{23}$ Dyrektywa nr 2004/17/WE Parlamentu Europejskiego i Rady z 31 marca 2004 r. koordynująca procedury udzielania zamówień przez podmioty działające w sektorach gospodarki wodnej, energetyki, transportu i usług pocztowych oraz dyrektywa nr 2004/18/WE Parlamentu Europejskiego i Rady z 31 marca 2004 r. w sprawie koordynacji procedur udzielania zamówień publicznych na roboty budowlane, dostawy i usługi, Dz. Urz. UE L 134, s. 114.

${ }^{24}$ Komisja Wspólnot Europejskich, Bruksela, 16 lipca 2008 r., KOM (2008), 400 wersja ostateczna, Komunikat Komisji do Parlamentu Europejskiego, Rady, Europejskiego Komitetu Ekonomiczno-Społecznego oraz Komitetu Regionów: Zamówienia publiczne na rzecz poprawy stanu środowiska $\{\operatorname{SEK}(2008)$ $2124\}\{\operatorname{SEK}(2008) 2125\}\{\operatorname{SEK}(2008) 2126\}$, s. 3-4.

${ }^{25}$ Co obejmuje takie surowce, jak: drewno, aluminium, stal, beton, szkło, a także wyroby budowlane, takie jak: okna, pokrycia ścienne i podłogowe, urządzenia grzewcze i chłodzące, aspekty dotyczące eksploatowania budynków i wycofywania ich z eksploatacji, usługi utrzymania budynków, realizacja zamówień na roboty budowlane na miejscu.

${ }^{26}$ W tym także elektryka, ogrzewanie i chłodzenie z wykorzystaniem odnawialnych źródeł energii.

${ }^{27}$ Biurowy sprzęt komputerowy obejmuje trzy zestawy produktów, tj. komputery (w tym zarówno komputery stacjonarne, jak i komputery przenośne, monitory) oraz urządzenia do przetwarzania obrazu (w tym kopiarki, drukarki, skanery, faksy i urządzenia wielofunkcyjne). Zakres ujętych produktów określono na podstawie normy Energy Star, Umowy między rządem Stanów Zjednoczonych Ameryki a Wspólnota Europejską w sprawie koordynacji programów znakowania efektywności energetycznej urządzeń biurowych oraz analiz przygotowawczych dotyczących PWE w odniesieniu do urządzeń do przetwarzania obrazu. Kryteria podstawowe dotyczące komputerów stacjonarnych, komputerów przenośnych i monitorów koncentrują się na uwzględnieniu specyfikacji technicznych związanych ze zużyciem energii. To bowiem właśnie ten aspekt określono jako najistotniej oddziałujący na środowisko. W zestawie kryteriów kompleksowych wskazano emisje hałasu, zastosowanie rtęci w układzie przeciwoświetlenia monitorów LCD, demontaż sprzętu, zastosowanie w częściach z tworzyw sztucznych środków zmniejszających palność, określonych niektórymi oznaczeniami ryzyka (rakotwórcze, mutagenne lub szkodliwe dla rozrodczości). Zob. Kryteria GPP opracowane przez Komisje Europejska (weryfikacja polskiej wersji językowej: M. Skowron, w: Zielone zamówienia publiczne); EcoDesign of EuP Products: Preparatory Studies LOT 4: Imaging Equipment: Copiers, Faxes, Printers, Scanners, MFD (Ekoprojekt 
włókiennicze, papier i usługi drukarskie, meble, środki czyszczące i usługi w zakresie sprzątania, jak również sprzęt wykorzystywany w służbie zdrowia" ${ }^{28}$. Przygotowano szereg krajowych kryteriów ${ }^{29}$, a także wypracowano wspólne kryteria odnoszące się do minimalnych specyfikacji technicznych, z którymi muszą być zgodne wszystkie oferty dla grup produktów i usług w 10 sektorach uznanych za najbardziej odpowiednie do wdrożenia ekologicznych zamówień publicznych.

Obecnie $\mathrm{w}$ niektórych sektorach zielone zamówienie publiczne sa wręcz uważane za obowiązkowe. Jest tak w wypadku informatycznych urządzeń biurowych, pojazdów transportu drogowego i budynków. Zgodnie z obecnie obowiązującymi przepisami, na mocy rozporządzenia w sprawie Energy Star (nr 106/2008) ${ }^{30}$, do zakupów informatycznych urządzeń biurowych przez organy administracji centralnej mają zastosowanie minimalne wymagania w zakresie efektywności energetycznej. Na mocy dyrektywy w sprawie ekologicznie czystych pojazdów $\left(2009 / 33 / \mathrm{WE}^{31}\right)$ przy zamówieniach publicznych na pojazdy powyżej wartości progowej określonej w przepisach UE instytucje publiczne muszą brać pod uwagę zużycie energii i emisje. Ponadto na mocy dyrektywy w sprawie charakterystyki energetycznej budynków $(2010 / 31 / \mathrm{UE})^{32}$ najpóźniej od 2014 r. we wszystkich nowych projektach budowlanych i w projektach ważniejszych renowacji muszą być stosowane minimalne wymagania dotyczące charakterystyki energetycznej. Komisja jest zaangażowana $\mathrm{w}$ promowanie ekologicznych zamówień publicznych dlatego, że widzi w nich niejako narzędzie promocji najmniej zanieczyszczających produktów i usług ${ }^{33}$. W Komunikacie Komisji Wspólnot Europejskich do Parlamentu Europejskiego, Rady, Europejskiego Komitetu Ekonomiczno-Społecznego oraz Komitetu Regionów KOM (2008), 400 - z 16 lipca 2008 r. ${ }^{34}$ odnotowano, że ,zamówienia publiczne moga kształtować trendy produkcyjne i konsumpcyjne, a znaczący popyt ze strony

dla produktów wykorzystujacych energie (PWE). Analizy przygotowawcze, cz. 4: Urzadzenia przetwarzajace obraz: kopiarki, faksy, drukarki, skanery, urzadzenia wielofunkcyjne). Zob. http://www. ecoimaging.org.

${ }^{28}$ Komunikat Komisji do Parlamentu Europejskiego, Rady, Europejskiego Komitetu, Ekonomiczno-Społecznego oraz Komitetu Regionów - Zamówienia publiczne na rzecz poprawy stanu środowiska, w: Zielone zamówienia publiczne, s. 99.

${ }^{29}$ Szerzej: Komisja Wspólnot Europejskich, Bruksela, 16 lipca 2008 r., KOM (2008), 400 wersja ostateczna, Komunikat Komisji do Parlamentu Europejskiego, Rady, Europejskiego Komitetu Ekonomiczno-Społecznego oraz Komitetu Regionów: Zamówienia publiczne na rzecz poprawy stanu środowiska $\{\operatorname{SEK}(2008) 2124\}\{\operatorname{SEK}(2008) 2125\}\{\operatorname{SEK}(2008) 2126\}$, s. 4. Zob. http://eur-lex.europa. eu/LexUriServ/LexUriServ.do?uri=COM:2008:0400:FIN:EN:PDF.

${ }^{30}$ Rozporządzenie Parlamentu Europejskiego i Rady (WE) nr 106/2008 z 15 stycznia 2008 r. w sprawie wspólnotowego programu znakowania efektywności energetycznej urządzeń biurowych. Warto odnotować, że samo znaczenie Energy Star ma charakter nieobligatoryjny, jednakże rozporządzenie stanowi o obowiązkowym stosowaniu podstawowych wymogów przez centralne organy rządowe i instytucje wspólnotowe w zamówieniach objętych dyrektywą w sprawie zamówień publicznych.

${ }^{31}$ Dyrektywa Parlamentu Europejskiego i Rady 2009/33/WE z 23 kwietnia 2009 r. w sprawie promowania ekologicznie czystych i energooszczędnych pojazdów transportu drogowego, http://eur-lex. europa.eu/LexUriServ/LexUriServ.do?uri = OJ:L:2009:120:0005:0012:PL:PDF.

${ }^{32}$ Dyrektywa Parlamentu Europejskiego i Rady 2010/31/UE z 19 maja 2010 r. w sprawie charakterystyki energetycznej budynków, Dz. Urz. L 153 z 18 czerwca 2010 r., s. 13-35, http://eur-lex. europa.eu/LexUriServ/LexUriServ.do?uri= OJ:L:2010:153:0013:01:PL:HTML.

${ }_{33}$ A. Matusiak, op. cit., s. 69.

${ }^{34}$ Zob. http://eur-lex.europa.eu/LexUriServ/LexUriServ.do?uri=COM:2008:0400:FIN:PL:PDF. 
instytucji publicznych na »bardziej ekologiczne« towary stworzy lub powiększy rynki dla przyjaznych dla środowiska produktów i usług. Tym samym zachęci to także przedsiębiorstwa do rozwijania technologii środowiskowych”. Komunikat zawiera także definicję ekologicznych zamówień, tzn. uznaje, że jest to ,proces, $\mathrm{w}$ ramach którego instytucje publiczne starają się uzyskać towary, usługi i roboty budowlane, których oddziaływanie na środowisko $\mathrm{w}$ trakcie ich cyklu życia jest ograniczone w porównaniu do towarów, usług i robót budowlanych o identycznym przeznaczeniu, jakie zostałyby zamówione $\mathrm{w}$ innym przypadku".

Warto też wspomnieć Komunikat Komisji: Europa 2020 - Strategia na rzecz inteligentnego i zrównoważonego rozwoju sprzyjającego włączeniu społecznemu $^{35}$, w którym wiele miejsca poświęcono kwestiom środowiskowym i wskazano, że „,budowanie zrównoważonej i konkurencyjnej gospodarki efektywnie korzystającej z zasobów, wykorzystując do tego pierwszoplanową pozycję Europy w wyścigu do nowych procesów i technologii”" ${ }^{36}$, w tym technologii przyjaznych środowisku może wzmacniać przewagę konkurencyjną europejskiego biznesu i uwolnić Europę z kryzysu. Dzięki inwestycjom w czyste i niskoemisyjne technologie poprawi się stan środowiska naturalnego, będziemy mogli skuteczniej przeciwdziałać zmianom klimatu oraz zwiększać potencjał w zakresie przedsiębiorczości i zatrudnienia ${ }^{37}$. Zdaniem Komisji właśnie dzięki takiemu podejściu Europa będzie „mogła prosperować w niskoemisyjnym świecie ograniczonych zasobów, jednocześnie zapobiegając degradacji środowiska, utracie bioróżnorodności i niezrównoważonemu wykorzystywaniu zasobów", a działania te zwiększą również spójność gospodarczą, społeczną i terytorialna ${ }^{38}$.

Jednym z głównych konsumentów informatycznych urządzeń biurowych sa instytucje publiczne. Dlatego też właśnie w tym obszarze istnieje ogromny potencjał oszczędności i jednoczesnej ochrony środowiska. Chodzi tu przede wszystkim o kwestię zarówno efektywności energetycznej, tj. pracy urządzenia w trybie działania, gotowości i wyłączenia, recyklingu, jak i np. ograniczeń dotyczących poziomu hałasu. Kryteria podstawowe dotycza przede wszystkim parametrów zużycia energii. Natomiast kryteria odnoszące się do okresu eksploatacji zostały dobrane na podstawie oznakowania ekologicznego $\mathrm{UE}^{39}$, tj. oznakowania „Błękitny anioł” (ang. Blue Angel) ${ }^{40}$ i oznakowania „Nordycki łabędź" (ang. Nordic Swan) ${ }^{41}$. W wypadku budynków należy brać pod uwagę wykorzystanie systemów energii odnawialnej, ograniczenie stosowania substancji niebezpiecznych $\mathrm{w}$ materiałach budowlanych, stosowanie drewna pozyskanego w sposób zrównoważony i innych materiałów naturalnych oraz

${ }^{35}$ KOM (2010) 2020, tekst dokumentu: http://ec.europa.eu/eu2020/pdf/1_PL_ACT_part1_v1.pdf.

${ }^{36}$ Zob. http://ec.europa.eu/eu2020/pdf/1_PL_ACT_part1_v1.pdf, s. 16.

37 Zob. http://ec.europa.eu/eu2020/pdf/1_PL_ACT_part1_v1.pdf, s. 13.

${ }^{38}$ Zob. http://ec.europa.eu/eu2020/pdf/1_PL_ACT_part1_v1.pdf, s. 16.

${ }^{39}$ Zob. http://ec.europa.eu/environment/ecolabel/index_en.htm

${ }^{40}$ Zob. http://www.svanen.nu/; kryteria na: http://www.svanen.nu/Eng/criteria/kriterie.asp? pgn $=44$.

${ }^{41}$ Zob. http://www.blauer-engel.de/index.htm; kryteria na: http://www.blauerengel.de/englisch/ vergabe/download_uz_e/e-UZ-014.pdf. oraz http://www.blauerengel.de/englisch/vergabe/download_ uz_e/e-UZ-072.pdf. 
pochodzących z recyklingu i wykorzystanych ponownie, a także promowanie recyklingu materiałów po zakończeniu ich użytkowania ${ }^{42}$. Istotne jest także przykładanie wagi do jakości powietrza wewnątrz budynku i właściwej wentylacji. Ponadto pożądane jest stosowanie instalacji oszczędzających wodę i zachęcanie do ponownego wykorzystywania wody szarej i wody deszczowej. Oprócz tego Komisja Europejska wskazuje również w tym zakresie na przenoszenie na wykonawców odpowiedzialności w ramach umowy za monitorowanie charakterystyki energetycznej przez kilka lat po zakończeniu budowy oraz za szkolenie użytkowników budynku w zrównoważonym zużyciu energii.

\section{DOBRE PRAKTYKI}

Tytułem przykładu dobrych praktyk można wskazać na estońskie ministerstwo środowiska, które w 2010 r. przeprowadziło przetarg na usługi w zakresie sprzątania, a do specyfikacji technicznej włączyło kryteria ekologiczne. Były wśród nich takie elementy, jak to, że wszystkie plastikowe worki muszą ulegać biodegradacji, odpady należy sortować (opakowania, odpady organiczne), papier toaletowy i ręczniki papierowe muszą być wyprodukowane $\mathrm{z}$ papieru pochodzącego z recyklingu. W efekcie okazało się, że dzięki temu uzyskano obniżenie kosztu usługi niemal o 10\% w stosunku do wcześniejszego, w którym zastosowane były dokładnie te same specyfikacje techniczne zamówienia ${ }^{43}$.

Warto również wskazać dobre praktyki na gruncie polskim. Dobrym przykładem może być casus kolektorów słonecznych w Wojewódzkim Szpitalu Specjalistycznym w Częstochowie, w którym zastosowane zostały energooszczędne technologie energetyczne ${ }^{44}$. Wpłynęło to także na kształtowanie świadomości społeczności lokalnej w zakresie poprawy efektywności energetycznej przy wykorzystaniu odnawialnych źródeł energii. Instalacja kolektorów słonecznych i ekonomizerów w Wojewódzkim Szpitalu Specjalistycznym w Częstochowie oddana została do użytku w 2007 r. Całkowity koszt inwestycji wyniósł ponad $4 \mathrm{mln} \mathrm{z}^{45}$. Władze placówki szacunkowo oceniają, że inwestycja przynosi średnioroczne oszczędności na poziomie przekraczającym 250 tys. zł. Zastosowana instalacja solarna została skojarzona $\mathrm{z}$ instalacja dotychczas wykorzystywana do uzyskania ciepłej wody użytkowej. Przynosi to duże oszczędności (do $100 \%$ w okresie od kwietnia do września) w opłatach za podgrzewanie wody użytkowej od zewnętrznego dostawcy lub $\mathrm{z}$ lokalnej

\footnotetext{
${ }^{42}$ Zob. Kryteria GPP opracowane przez Komisje Europejska, passim.

${ }^{43}$ Więcej przykładów dobrych praktyk na: http://ec.europa.eu/environment/gpp/case_en.htm.

${ }^{44}$ Przykłady innych dobrych praktyk dostępne również w: M. Skowron, Zielone zamówienia publiczne - II Podręcznik, Urząd Zamówień Publicznych, Warszawa 2012, s. 107 i n.

${ }^{45} \mathrm{Na}$ realizację instalacji placówka otrzymała bezzwrotną dotację w wysokości $2 \mathrm{mln} 208$ tys. od Ekofunduszu i Wojewódzkiego Funduszu Ochrony Środowiska i Gospodarki Wodnej, a także uzyskała pożyczkę z tego samego WFOŚSiGW w wysokości ponad 40\% kosztów inwestycji źródło: M. Skowron, Zielone zamówienia publiczne..., s. 107 i n.
} 
kotłowni. Bezsprzecznie zastosowana $\mathrm{w}$ tym wypadku technologia jest przyjazna dla środowiska, zmniejsza zużycie paliwa oraz emisję dwutlenku węgla ${ }^{46}$.

\section{CZY UDA SIE ,ZAZIELENIĆ” ZAMÓWIENIA PUBLICZNE?}

Mówiąc o korzyściach płynących ze stosowania tzw. zielonych zamówień publicznych, należy mieć na uwadze możliwość realizacji określonych celów i zadań środowiskowych. Przykładem może być redukcja emisji $\mathrm{CO}_{2}$, efektywność energetyczna, ochrona zasobów naturalnych, oszczędność kosztów, sprzyjanie innowacyjności i wspieranie rozwoju konkurencyjnych, zielonych towarów i usług oraz poszerzanie rynku tych produktów, tworzenie zdrowszych warunków pracy dla pracowników. Warto też wskazać, że ekologiczne zakupy mogą prowadzić nie tylko do korzyści dla środowiska, lecz także - co przecież nie pozostaje bez znaczenia - do oszczędności. Dzięki uwzględnieniu takich czynników, jak chociażby zużycie energii i wody, odpowiednie gospodarowanie odpadami, ograniczenie stosowania pewnych substancji, stosowanie materiałów pochodzących z recyklingu, zielone zamówienia publiczne mogą pomóc w osiągnięciu oszczędności. Coraz więcej mówi się o tym, że wzrost dobrobytu nie powinien być osiagany kosztem środowiska naturalnego i ludzkiego zdrowia. Oznacza to, że osiągnięcie celów zrównoważonego rozwoju będzie możliwe przy jednoczesnym zintegrowaniu polityki środowiskowej z polityką gospodarczą i społeczną. Należy zachęcać przedsiębiorstwa do rozwijania technologii środowiskowych. Nie wolno zapominać, że bardziej zrównoważone wykorzystanie zasobów naturalnych i surowców będzie korzystne zarówno dla środowiska, jak i dla całej gospodarki. Ze względu na interes społeczny, poprawę jakości życia i stanu środowiska naturalnego ważne jest, aby w zamówieniach publicznych aspekty środowiskowe były uwzględniane w możliwie jak najszerszym zakresie. Należy podkreślić, że co prawda zielone zamówienia publiczne stanowią instrument dobrowolny, niestety obecnie w Polsce kryteria środowiskowe są przez zamawiających stosowane nad wyraz rzadko.

mgr Anna Matusiak

${ }^{46}$ Ibidem, s. 107-108. 


\section{TREND SHAPING IN THE DEVELOPMENT OF GREEN PUBLIC PROCUREMENT AND THE EUROPEAN UNION LAW REGULATIONS}

\section{Summary}

Green Public Procurement denotes a proceeding in which the procurement process involves at least one environmental factor already present at the needs assessment stage, when the subject of procurement is defined, its technical specifications formulated, and the procurement criteria or the manner in which it will be conducted are decided upon. The aim of the GPP is to determine the environmental issues in the tendering procedures to the fullest possible extent. The main idea behind the GPP is establishment of clear and challenging ecological criteria for products and services. Green Public Procurements are not obligatory, only recommended, and sadly not at all popular in Poland where ecological criteria in tenders are seldom respected, despite the fact that if properly promoted, in a long perspective GPP could bring considerable profits to all the environment. 
Copyright of Journal of Law, Economics and Sociology is the property of Faculty of Law and Administration of Adam Mickiewicz University in Poznan and its content may not be copied or emailed to multiple sites or posted to a listserv without the copyright holder's express written permission. However, users may print, download, or email articles for individual use.

Właścicielem praw autorskich do „Ruchu Prawniczego, Ekonomicznego i Socjologicznego” jest Wydział Prawa i Administracji Uniwersytetu im. Adama Mickiewicza w Poznaniu. Zawartość czasopisma nie może być kopiowana, przesyłana do innych stron internetowych bądź zamieszczana na blogach bez pisemnej zgody wydawcy. Niemniej artykuły można drukować, kopiować lub przesyłać w formie elektronicznej na własny użytek. 